\title{
The Jurchens' Religious Construction on the Obrivistiyi Cape in Primorye
}

\section{Nadezhda G Artemeva*}

Department of Medieval Archaeology at the Institute of History, Archeology and Ethnography of Peoples of the Far East, Far Eastern Branch of the RAS, Russia

*Corresponding author: Nadezda G Artemeva, Head of the Department of Medieval Archaeology at the Institute of History, Archeology, and Ethnography of Peoples of the Far East, Far Eastern Branch of the Russian Academy of Sciences, Vladivostok, Russia, Tel: 423222-80-67; E-mail: artemieva_tg@list.ru

Rec date: Mar 30, 2016; Acc date: Apr 11, 2016; Pub date: Apr 16, 2016

Copyright: @2016 Artemeva NG. This is an open-access article distributed under the terms of the Creative Commons Attribution License, which permits unrestricted use, distribution, and reproduction in any medium, provided the original author and source are credited.

\begin{abstract}
The Jin ritual construction located on the Obrivistiyi Cape in Primorye was discovered in 2001. It was dated back to XII-XIII. Its square was $160 \mathrm{~m}^{2}$. The long side of the construction was orientated from the north-east to southwest. The entrance was situated on the southwestern part of the narrow side. The risen up floor in the center of the building was used as a place of shrine. The temple had V-shapes roof without any molding decorations. Nowadays it is the largest and to some extent, the most significant place of worship of that period in Primorye. Archeological research revealed some typical architectural features of the Jin temples (a sort of confluence of the Jurchen and Chinese buddhistic architectural traditions). Plenty of roofing tiles, some weaponry and tools were excavated there.
\end{abstract}

Keywords: Jurchen; Jin dynasty; Ritual construction; Temple; Roofing tile; Obrivistiyi cape; Primorye

\section{Introduction}

The research of medieval archaeology of the Russian Far East has been conducting for a few decades. The large amount of archaeological materials relative to the culture of the Jurchens Jin Empire (1115-1234) and the Eastern Xia State (1215-1233) has been collected for that period. The Jin Dynasty was established by the Wanyan clan of the Jurchen people, the ancestors of the Manchu people who founded the Qing Dynasty, and lasted until the Mongols' invasion in 1234. In 1127 the Jurchens during the Jin-Song wars conquered the Northern Song and gained control of most of northern-east China. The Jurchens migrated to that area and adopted many Chinese cultural features and religious beliefs (including Buddhist, Taoistic and Confucian practices). The short-lived kingdom of Eastern Xia was founded by a Jurchens warlord Puxian Wannu, who rebelled against Jin in 1215. The kingdom was located on the territory of the modern Far East of Russia in Primorye. In 1233 the Mongols attacked the Eastern Xia with a large force and captured Puxian Wannu. The Jin Dynasty was overthrown in the next year.

There are 50 Jurchens' walled towns, numerous sites and settlements in Primorye. A plenty of archeological artifacts and remains excavated allowed us to obtain abundant information about the architectural features of the Jurchens' constructions.

In most cases, the researchers paid key attention to the town planning, home units and administrative buildings, but they did not focused on the religious architecture. Nine buddhistic constructions (eight temples and one additional building) were discovered on the territory of the Far East of Russia [1-6]. According to the cultural deposits, they were dated back to three chronological periods - VII-X (Balhae period), XIII (Yuan period) and XV (Ming period) [7,8]. Until recently, the religious constructions of Jin period (XII-XIII) have not been found in Primorye. The first Jin temple was excavated on the territory of the Krasnopoliye site and the second one-on the Obrivistiyi Cape.

This study summarizes data concerning the Jurchens' religious construction the above mentioned temple on the territory of the Obrivistiyi Cape (including its natural surroundings, inner planning, architectural features, decoration items and archeological artifacts excavated there).

\section{Temple on the Obrivistiyi Cape: Inner planning}

The religious structure located on the Obrivistiyi Cape was discovered by the members of archaeological expedition under an academic supervision of Kluev [9]. The Cape was situated on the territory of Muravinaya Bay in two kilometers to the south-west from Shkotovo village [9]. Height of the Cape approximately was 20 meters; its western part faced the sea (Figure 1). There was a ground platform with a low earthwork and a ditch around it on the top of the Cape. Some fragments of medieval roofing tiles were found in the ditch. According to the shape and location of the construction, the researchers considered it to have performed some administrative or religious functions.

The long side of the platform was orientated parallel to the western part of the Cape. Four corners of the platform were decorated by some big basaltic boulders. There were some plain squares that could be used as bases of buildings in the southwestern part of the Cape. The square of the settlement was about 2000 square kilometers. Until the middle of the 90th of XX, a military unit was located on this territory, so that nowadays the original topography of the site is not visually accessible. There were also three plain squares near the hillside on the northwestern part of the Cape (Figures 2-7). 
Citation: Artemeva NG (2016) The Jurchens'Religious Construction on the Obrivistiyi Cape in Primorye. J Socialomics 5: 163. doi:10.41 $72 / 2167-0358.1000163$

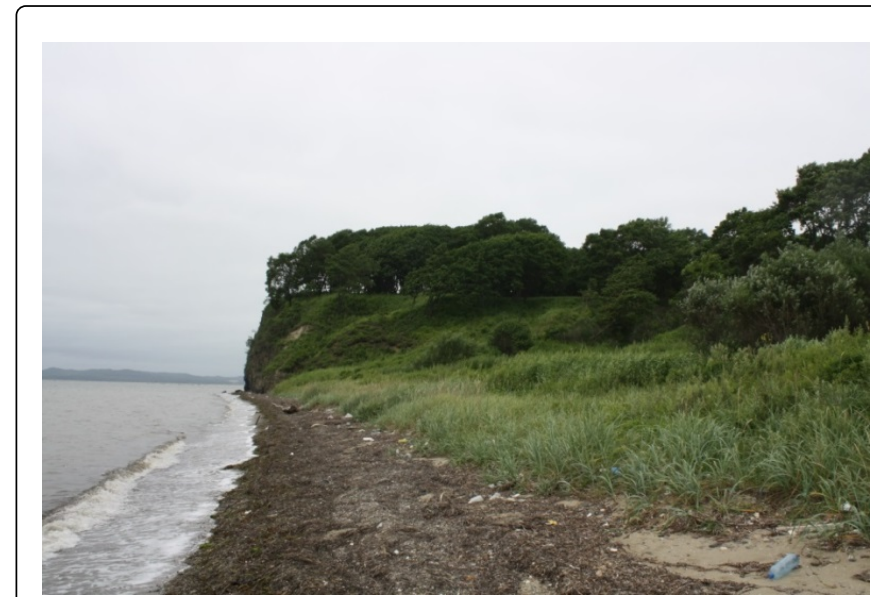

Figure 1: The Obrivistiyi Cape: View from the southern part.

After removing the upper level of soil, we excavated the stone walls of two four-cornered platforms ( $\mathrm{S}=360$ square meters; 2415 meters) with stone basement of the buildings inside them. Distance between the platform's border and the basements were about two meters wide. The whole place was covered with a $40 \mathrm{~cm}$ level of the roofing tiles (Figures 2 and 3 ).

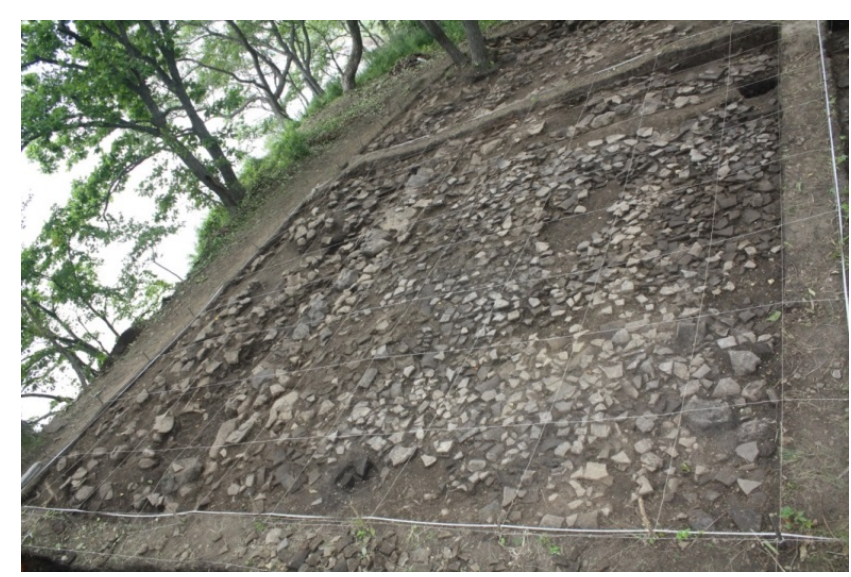

Figure 2: Clearing-up of the layer 1: View from the southeast.

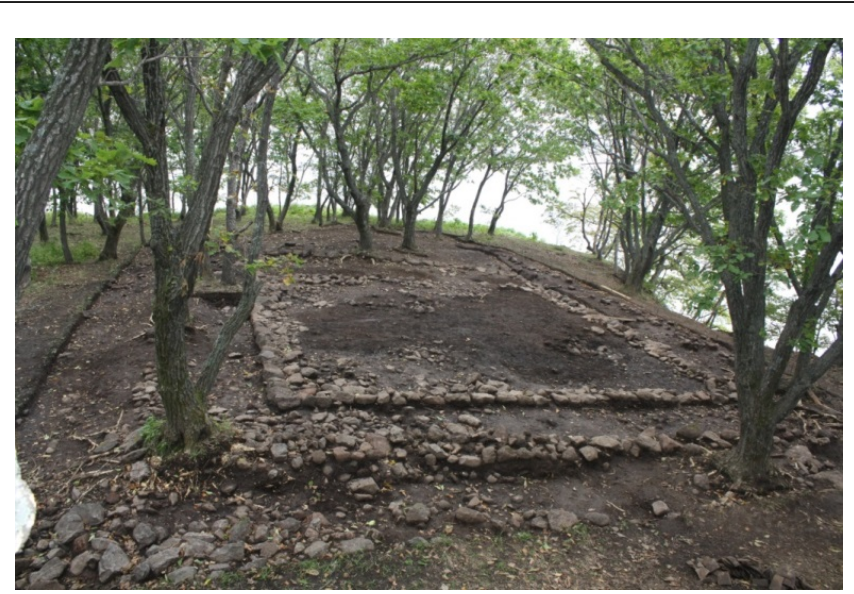

Figure 3: Stone platform of the temple: View from northeast.

We found a patch of lowland between the stone decoration of the platform and the basement. It was $0.2 \mathrm{~m}$ deep and was filled with a great deal of the tiles. We also managed to find some fragments of clay luting (Figure 7-7.2), burnt wooden pieces and iron nails. We found only some frequent fragments of the broken roofing tiles on the stone covering level of the platform and the floor of the building. Perhaps, the distance between an edge of the roof and a wall of the building was about 1 meter wide, therefore when the roof was destroyed; the tiles of the slope of the roof fell down exactly on that place.

The building itself was four-cornered in shape with square of 160 square meters $(16 \times 10 \mathrm{~m})$. These four corners were orientated according to the cardinal directions (Figure 4). A lower part of the building's walls was set on the solid foundation made of large flat stones. The inner part of the foundation was strengthened with smaller flat stones. Though the building was constructed on a basalt rock, its edges were strengthened with plenty of small stones. It can be apparently seen in the southern corner of the structure. The entrance of the building was located in the central part of the southwestern wall. It had a stone sill. The distance between the sill and the border of the platform was about 5 meters wide. 


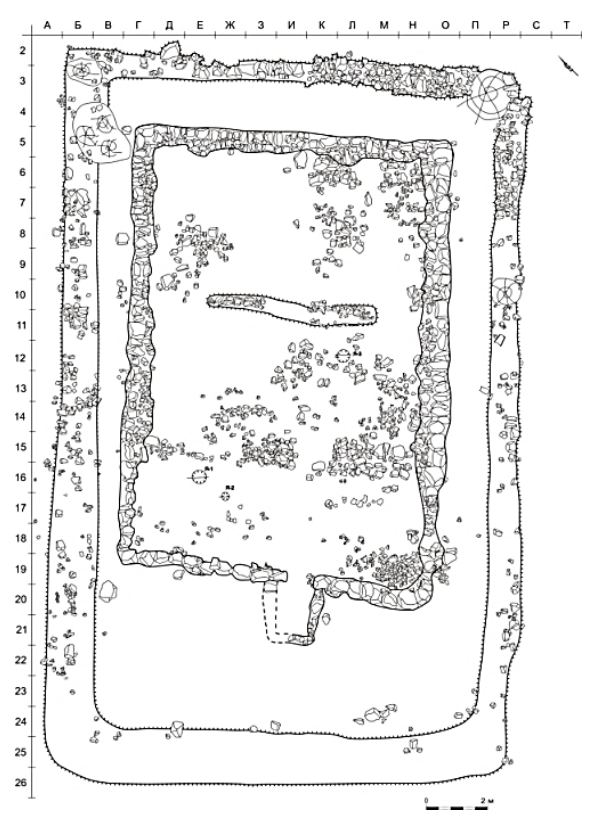

Figure 4: Plan of the temple on the Obrivistiyi Cape.

The floor in the central part of the building was situated on the upper level ( 0.3 meters higher than the floor in the other parts of the structure). This part of the floor was rectangular in shape $(7 \times 4)$ and its two sides were strengthened with stones. We consider this part of building to have been the location of a chancel.

\section{Roofing tiles of the temple}

The research of this building resulted in collecting of a large amount of the roofing tiles (about 8 tons). An average weight of one tile is 2.5 $\mathrm{kl}$. We estimated that the roof of the building had been made of 3200 roofing tiles; such amount of the tiles could cover the roof with square of more than 100 square meters.

We managed to gather 100 complete tiles. They looked like the sleeves made of grey clay (a width of a big chord was $20-24 \mathrm{~cm}$, a width of a small one was $16-21 \mathrm{~cm}$, a length of the sleeve was $32-37 \mathrm{~cm}$, its width was $1-2 \mathrm{~cm}$ ). The outer side of the tile was flat (sometimes with some scratches). There was a printed ornament on the inner side of tile. This ornament was made with a coarse cloth that had been put under the tile during the process of its molding. According to the ornament's texture, the Jurchens used the cloth of the plant origin. Pattern form of the down tile was truncated conical in shape. The diameters of its wide and narrow edges were $20-24 \mathrm{~cm}$ and 16-21 respectively. The height of the pattern form was $32-37 \mathrm{~cm}$. There were also four vertical fins on the outer side. They were used while cutting the tile and taking it out of the pattern forms after drying.

Some clay lines could be obviously seen on the outer part of each tile. Their width was $3-5 \mathrm{~cm}$. These lines were imprinted with the cloth ribbons that had been used for wrapping the pattern form during the process of molding. There were also some prints of wooden sticks. These sticks had been set vertically upon the pattern forms. The width of their prints was $1-1.5 \mathrm{~cm}$ (Figure 5:1). There were some prints of vertical (Figure 5:2) and more rarely horizontal seams, cloth patches and bends (Figure 5:3,4) as well as four paired dents made with the devices that had been used for taking the dry tile out of the pattern form.
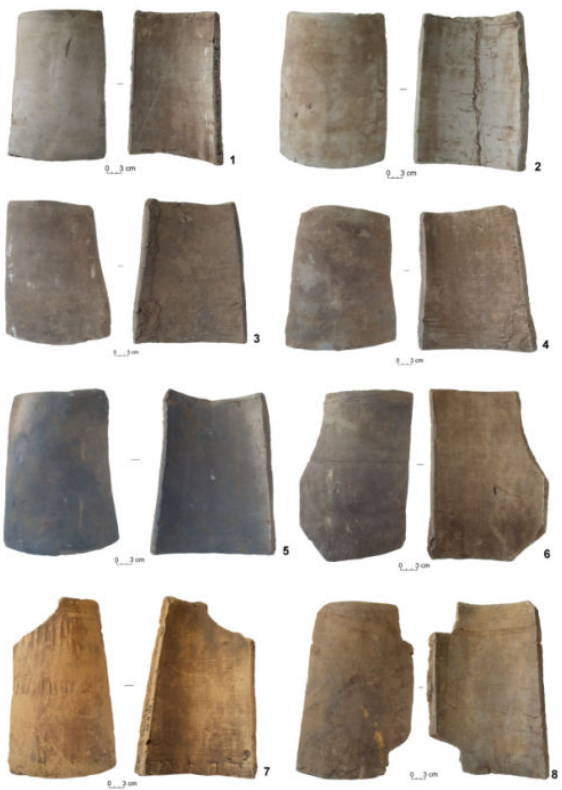

Figure 5: Down roofing tiles.

Down edges of the tiles were flat because they had been cut with a knife. Width of the side edges throughout the length of the tile is not the same. It is narrower in the upper part of the tile than in its down side. The upper narrow edge was flat and smooth without any cloth prints on its inner side. It must have been formed with an oblong piece of clay that had been put into proper shape with a knife. We also excavated some defective tiles and some tiles with marking scratches on their surfaces. The most part of the tile was grey (different tones of that colour), much rarely we found orange fragments. The Jurchen people used the reducing firing system of burning the tiles (it means that there was no oxygen access in the furnace and the temperature of burning was about $1000^{\circ} \mathrm{C}$ ).

The size of these tiles and production technique are completely identical with the ones of the other medieval sites (XII-XIII) in Primorye. The only difference is in fact that we have excavated the tiles of a very high (flat, evenly burnt) as well as rather low (wider than the standard tiles, unevenly burnt, with some defects occurred after drying) qualities. Therefore, we consider these tiles to have been produced in different workshops.

\section{Artifacts excavated}

There is a large amount of the iron nails among all excavated items (Figure 6:5-12). A total of 89 nails were found. They all were forged. Their length was $4-5 \mathrm{~cm}$. The most part of the nails was excavated on the area around outer side of a building's wall. The bowl of a glazed vessel (Figure 7:1,2), fragment of a vase's stopper ring (Figure 6:13), iron arrowhead (Figure 7:3), basaltic beetle and Kaiyuan tongbao coin (621-713) (Figure 6:14) were found there. According to the amount of the artifacts excavated, this building was not destroyed and ransacked by the Mongols. 


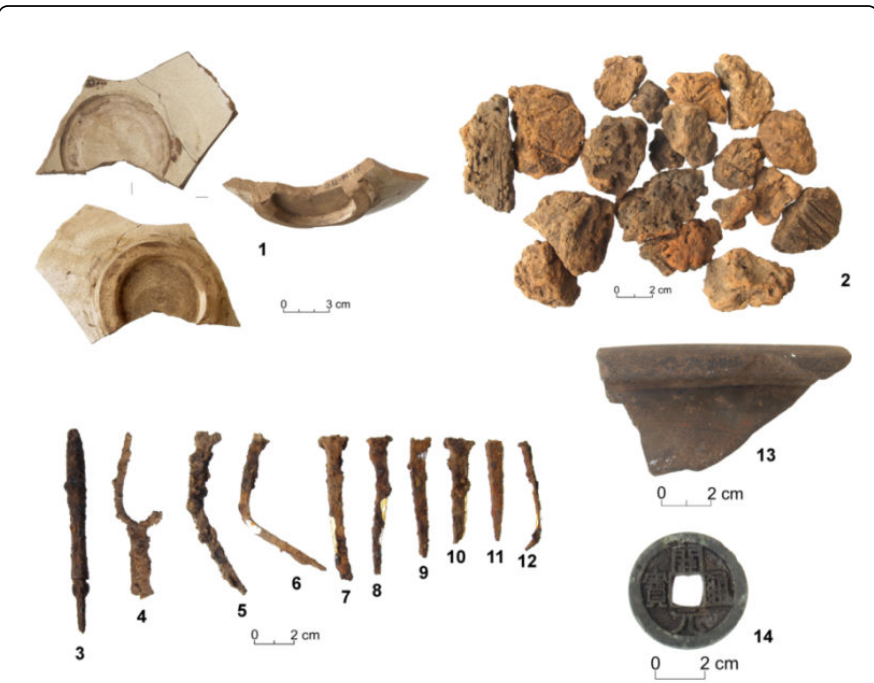

Figure 6: Artifacts: 1-fragment of the glazed bowl with a saucer (faience); 2-fragment of a plaster (clay), 3-arrowhead (iron); 4fragment of a scissors (iron); 5-12-nails (iron); fragment of a vaseshaped vessel (ceramics); kaiyuan tongbao coin (bronze).

\section{Natural surroundings and some architectural features}

The structure on the Obrivistiyi Cape was built in a close accordance with the architectural traditions of medieval religious constructions. The specific features of the temple's architecture matched with the landscape: the building was constructed in the middle of a long axis of the cape, its four corners was orientated to the cardinal points. This kind of location-mountains in the east and sea in the west is likely to have been nearly connected with the geomancy and other religious beliefs of the Jurchen people. While choosing the suitable place for building the temple (most probably, the buddhistic one), they must have taken into accounts such natural conditions as the location of mountains, cardinal directions, set of a water current and so on.

The architectural features of the temple are quite similar to the ones of Buddhistic, Confucian and Taoistic religious constructions. The building was set on the basement $\left(\mathrm{S}=360 \mathrm{~m}^{2}\right)$, it had a tile roof that was supported with wooden columns. We did not manage to find any column bases. We think that the Jurchens did not have to use such constructing technique, because the floor of the building was naturally formed with a ledge rock of the cape. The whole square of the building was $160 \mathrm{~m} 2$. The direction of its long side was from the northwest to the southwest. The entrance was located in the south-western part of the narrow side of the building. It was decorated with a small staircase. The floor in the center of the structure was raised up. In our opinion, the temple's altar was erected there. The building has V-shaped roof without any molding decoration items. We found only two fragments of the tile with so-called "finger" and "fir-tree" ornaments on them (Figures 7:4 and 7:5).

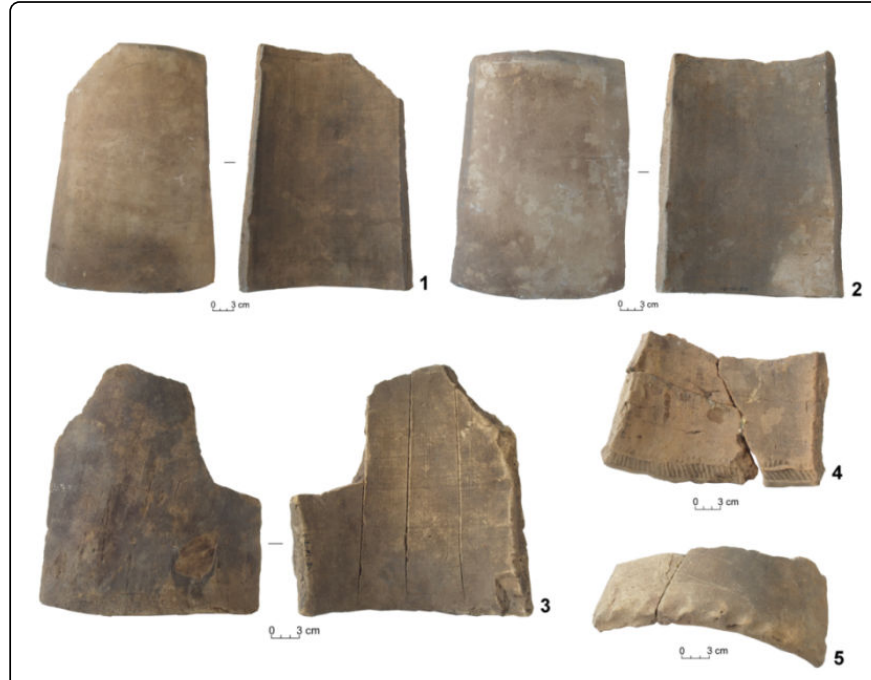

Figure 7: 1 and 2-down roofing tiles; 3-roofing tile with marking for cutting on its surface; 4 and 5 -fragments of the decorated down tiles.

The period of the temple constructing was determined by means of the dating the tile and ceramic dishes excavated. There is no difference in the size, ornaments and producing techniques between the tiles from the Obrivistiyi Cape and the other Jurchen sites of XII-XIII situated in Primorye. We can see quite the same situation in ceramics collected on territory of the Cape. The position of the fallen tiles shows that the temple was destroyed by the nature; it did not suffer from the invader's fire.

The temple on the Obrivistiyi Cape must have been a religious building of great importance and significance. Nowadays it is the largest place of worship in Primorye. There might be some additional buildings that were included into the Buddhistic architectural complex. Some small single-store Jurchen temples installed on the brick basements were found on the territory of the Northeast of China [10]. The inner columns supported the roof of such temple were higher than outer ones in 1, 4-1, 8 times, so that a so-called "flying roof" effect was created. The bottoms of the column were put beneath the floor and did not have any ornaments on them. The height of purlins and the system of roof framing depended on the form of the roof's pitch. These temples usually had pitched, pointed or pyramidal broach roofs. They, unlike the roofs of administrative buildings, were covered with nondecorated tiles.

\section{Ritual construction on krasnopoliye site}

The temple on the Obrivistiyi Cape is the second religious structure found on the territory of Primorye, the first one was found near the Krasnopoliye village [11]. This temple was built on the basement. It square was $5 \times 6$ meters. Its columns rested on six stone bases supported a pitch tile roof. The entrance was built on the southeastern part of the temple.

The main specific features of the building were the bases supported the roof and located on the ground platform as well as the pillars of the temple's framework built under the inner part of the platform. We have never found this type of architectural technique yet. We excavated a large amount of lower tiles and only tree ornamental fragments. There 
were some fire-marks on the tiles, because the temple itself was destroyed by fire.

An artificial terrace was constructed to the south direction from the entrance. Its square was $4 \times 9$ meters. We consider it might be used as a place for hanging the temple's bell. We found the ruins of a half dugout $\left(\mathrm{S}=9 \mathrm{~m}^{2}\right)$ in the western part of the temple. It has a kang heating system. In our opinion, this dugout could shelter one or two keepers who took care about the temple.

The location of the temple was very well-chosen: it was covered with the mountains on one side and faced the sea on the other side. The river connected all medieval sites of the Partizanskaya valley ran below the cape and was a waterway to it. The visual field that could be seen from a top of the cape was very large; it included an access to the sea and Nikholayevskoye site. Besides that, the territory of the temple might also perform an observation function; a system of signal lights could be set up there.

The square of the temple in Krasnopoliye site was five times smaller than the one on Obrivistiy Cape, therefore the religious status of these two places of worship was different, too.

\section{Conclusion}

The Jin religious architecture certainly developed within the frameworks of the far-eastern architectural traditions and worked out its own specific features. Temple complexes in the metropolitan regions were built in a close accordance with a classical religious architecture and at the same time, the temples in the remote areas had their own architectural features.

The locations and architectural styles of the temples of Krasnopoliye site and the Obrivistiyi Cape are very similar to the ones of such buddhistic temples of Balhae period as Abrikosovskiy, Kopitinsky and Tirskiy (XV) $[1,6]$. All of them were built on the highlands, rather far from either towns or villages. While constructing medieval architects took into account the natural landscape (mountains, water arteries etc.). Our Japanese colleagues suppose that there are many similarities between Balhae temples of Primorye and religious constructions of India and Central Asia; and Balhae culture largely succeeded architectural traditions of the Goguryeo Kingdom [12]. Chinese scientists consider that Balhae people tried to imitate Chinese architectural styles [13]. Some interesting information concerning the etymology of the Jurchens' term "buddhistic temple" was collected by Vorob'ev [10]. This term originates at the Korean word "tyol" (temple). We consider it to be a reliable evidence of the fact that this term had come to the Jurchens from Korea earlier than they began to keep close contacts with the Khitan people [10]. We have a reason to suppose that the Jurchen built their temples in compliance with the Korean Phunsu doctrine [14].

The origin of the Jurchens Buddhism is a quite complicated question. It is considered to have been come to the Jurchens first of all from Korea and then from the Khitans. The Jurchens' first buddhistic temples were constructed at the turn of XIIth century. The main special feature of the Jurchens' Buddhism was a sort of confluence of the ideas of classical Buddhism, Taoism and Confucianism and creating the conglomerate of these three religious doctrines [15]. Therefore, we consider that there may be no difference between the Buddhistic and Taoist temple architecture.

\section{References}

1. Artemev, Alexander R (2005) Buddiyiskiye hrami XV nizov'yah Amura. Buddhistic temples in the lower reaches of Amur: Vladivostok: LLC K partneri Press in Russian 202.

2. Artemeva, Nadezhda G (1998) Kultoviye sooruzheniya bohaiskogo vremeni Na territoriyi Primor'ya Religious structures of the Balhae period on the territory of Primorye Possiyiskaya arheologiya. Moscow: Institut Arheologiyi RAN Press Russia fjin174-191.

3. Boldin, Vladislav I (1987) Rasskopki buddiyiskogo hrama na Kraskinskom gorodishe. Excavations of the buddhistic temple in the Kraskinskoye site in Issledovaniye pamyatnikov drevnih kul'tur Sibiri I Dal'nego Vostoka: Novosibirsk: Institut Arheologiyi i Etnografiyi SO RAN 189-190.

4. Boldin, Vladislav I (1993) Budiyiskiyi hram Kraskinskogo gorodisha [Buddhistic temple of the Kraskinskoye site] in Problemi etnokul'turnoyi istorii Dal'nego Vostoka b sopredel'nih territoriyi: Blagoveshinsk Press (in Russian) 49-59.

5. Medvedev, Vitaliyi E (2001) Bohayiskaya kumirnya v Primor'e Balhae temple in Primorye, Seoul: Institute of Goguryeo Press (in Korean and Russian) 467.

6. Shavkunov Ernst V (1968) Gosudarstvo Bohai i pamyatniki ego kulturi v Primor'e The Balhae State and the sites of its culture in Primorye Leningrad: Nauka Press (in Russian) 128.

7. Artem'eva, Nadezhda G (2009) Arhitektura buddiyiskih hramov na Dal'nem Vostoke (po archeologicheskim issledovaniyam) Architecture of buddhistic temples in the Far-East (based on archaeological research), in Ot Mongolii do Primoriya i Sahalina. Tihookeanskaya arheologoya. Semnadtsatiyi vipusk: Vladivostok: DVGU Press (in Russian) 235-269.

8. Kluev, Nikholay A (2001) gody Field report on archeological investigations of the northern and central parts of Primorye in 2001Archive Fond 1, No. 471, Institute of History, Archaeology and Ethnography of Peoples of the Far East, Vladivostok (In Russian).

9. Vorob’ev, Mikhail B (1983) Kul'tura jurchjeneyi i gosudarstva Jin (X v. 1234 g.) Culture of the Jurchens and the Jin State:Moscow: Nauka Press (in Russian)183-185.

10. Artem'eva, Nadezhda G (2014) Issledovaniye pervogo buddiyiskogo hrama XII-XIII vv. na territoriyi Primor'ya Research of the first buddhistic temple of XII-XIII centuries on the territory of Primorye in Vestnik istoriyi, literature, iskusstva. Al'manah, V. XI: Moscow: Sobraniye Press (in Russian).Press (in Russian) 7-18.

11. Kan, Edani (1966) Abrikosovskiyi hram bohayiskogo vremeni The abrikosovskiyi temple of the Balhae period in Paleologiya, (in Japanese) 13:123-137

12. Wei, Cuncheng (1984) Architekture Bohaya [Balhae architecture] in Heilongjiang wenwu congkan Harbin: Heilongjiang wenwu Press (in Chinese) 4:18-22.

13. Tian (2001) Buddhiyiskiye hrami srednevekovoyi Korei. Istoriya, architektura, filosofiya Buddhistic temples of medieval Korea. History, architecture, philosophy: 174. Moscow: Vostochnaya literature RAN Press (in Russian) 62-68

14. Vorob’ev, Mikhail B (1966) Religiozniye verovaniya jurchjeneyi Religious beliefs of the Jurchens in Dokladi po ethographii. Vipusk Leningrad: Geographicheskoye obshestvo SSSR Press (in Russian) 4:61-82.

15. Artem'eva, Nadezhda G (2012) Pervaya churdchen'skaya kultovaya postroyika Na territoriyi Primor'ya The first Jurchens' religious structure on the territory of Primorye, in Dal'nevosttochno-Sibirskiye drevnosty. Sbornik nauchnih trudov, posvyashennih 70-letiu so dniya rozhdeniya VE Medvedeva: 122-131. Novosibirsk: Institut Arheologiyi i Etnografiyi SO RAN Press (in Russian). 